\title{
PROGRAM MULTI LEVEL MARKETING GENERASI BERENCANA KABUPATEN PASURUAN PERSPEKTIF MASLAHAH MURSALAH
}

\author{
Fitrya Dwi Murti dan Zayin Chudlori
}

Fakultas Syari'ah dan Hukum UIN Sunan Ampel Surabaya. E-mail: dwimurtifitrya@gmail.com

\begin{abstract}
This article discusses the theory of mashlabah mursalah on the Multi Level Marketing Planning Generation Program (MLM Genre) of the Family Planning and Women's Empowerment Office in Pasuruan Regency. From the research on the MLM Genre program organized by the Family Planning and Women's Empowerment Office of Pasuruan Regency, it can be concluded: First, this program has not been implemented properly because the program should have been implemented in every sub-district in Pasuruan Regency, which amounted to twenty-four Districts, but for now it is still running in five districts only. Among the factors is the lack of awareness of the Pasuruan community to participate in running the program. Second, the Multi Level Marketing Planning Generation Program organized by the Family Planning and Women's Empowerment Office of Pasuruan Regency in terms of activities and material delivered by the Family Planning and Women's Empowerment Office of Pasuruan Regency provides benefits for adolescents and the surrounding community who will get married. In the perspective of the maslabah mursalah, it has fulfilled the requirements of the mashlahah, and does not contradict to the texts, real, general in nature, and has many benefits.
\end{abstract}

Keywords: Maslahah mursalah, MLM Genre, Pasuruan.

Abstrak: Artikel ini membahas tentang Analisis Maslahab Mursalab terhadap Program Multi Level Marketing Generasi Berencana (MLM Genre) Dinas Keluarga Berencana dan Pemberdayan Parempuan di Kabupaten Pasuruan. Dari penelitian mengenai program MLM Genre yang diselenggarakan oleh Dinas Keluarga Berencana dan Pemberdayaan Perempuan Kabupaten Pasuruan dapat disimpulkan: Pertama, program ini belum terlaksana dengan baik karena yang seharusnya program tersebut dilaksanakan di setiap kecamatan yang ada di Kabupaten Pasuruan yang berjumlah dua puluh empat Kecamatan, namun untuk saat ini masih berjalan di lima kecamatan saja, di antara faktornya adalah kurangnya kesadaran masyarakat Pasuruan untuk berpartisipasi dalam menjalankan program tersebut. Kedua, program Multi Level Marketing Generasi Berencana yang diselenggarakan oleh Dinas Keluarga Berencana dan Pemberdayaan Perempuan Kabupaten Pasuruan dilihat dari segi kegiatan maupun dari materi yang disampaikan oleh Dinas Keluarga Berencana dan

AL-HUKAMA

The Indonesian Journal of Islamic Family Law Volume 09, Nomor 02, Desember 2019; ISSN:2089-7480 
Pemberdayaan Perempuan Kabupaten Pasuruan memberikan manfaat bagi remaja dan masyarakat sekitarnya yang akan melangsungkan pernikahan. Dalam perspektif maslabah mursalab telah memenuhi syaratsyarat Maslahah mursalah yaitu tidak bertentangan dengan nash atau dalildalil qath'i, bersifat nyata, bersifat umum, dan memiliki banyak kemaslahatan.

Keywords: Maslahah mursalah, MLM Genre, Pasuruan.

\section{Pendahuluan}

Manusia merupakan salah satu makhluk ciptaan Allah yang paling sempurna jika dibandingkan dengan yang lainnya. Allah menciptakan manusia untuk saling berpasang pasangan yang mana disebutkan dalam firman Allah surat Adz-Dzariyat Ayat 49: Dan segala sesuatu kami ciptakan berpasang pasangan agar kamu mengingat (kebesaran Allah).1

Islam mensyariatkan pernikahan kepada manusia agar ia tidak seperti makhluk lainnya yang hidup bebas mengikuti nalurinya dan berhubungan antara laki-laki dan perempuan secara anarki tanpa ada aturan. Demi menjaga kehormatan dan martabat kemuliaan manusia selaku khalifah Allah di muka bumi, maka diadakanlah hukum yang sesuai dengan martabatnya.2

Keluarga merupakan batu pijakan orisinal dan institusi tertua yang tidak ada gantinya dalam membangun masyarakat. 3 Perkawinan merupakan sunnatullah yang umum berlaku pada semua makhluk tuhan, baik pada manusia, hewan maupun tumbuhtumbuhan.4 Tujuan perkawinan dalam Islam selain untuk memenuhi kebutuhan hidup jasmani dan rohani manusia, juga sekaligus untuk membentuk keluarga dan memelihara serta meneruskan keturunan dalam menjadikan hidupnya di dunia ini, juga mencegah perzinahan, agar tercipta ketenangan dan ketentraman jiwa bagi yang bersangkutan, ketentraman keluarga dan

1 Departemen Agama RI, Al-Qur'an dan Terjemahannya (Bandung: Diponegoro, 2010), 522.

2 LM Syarifie, Membina Cinta Menuju Perkawinan (Gresik: Putra Pelajar, 1999), 10. 3Muhamad Iqbal, Psikologi Pernikahan Menyelami Rahasia Pernikahan (Jakarta: Gema Insani, 2018), IX.

4 Sayyid Sabiq,Fikih Sunnah 6, terjemah, Moh Thalib (Bandung: Alma'arif, 1990), 9. 
masyarakat.5 Hal itu sebagaimana tercantum dalam Alquran yang dikenal dengan istilah sakinah, mawaddah, wa rahmah. Sebagaimana telah Allah Swt jelaskan dalam QS. al-Rum ayat 21:

Artinya: Dan di antara tanda-tanda (kebesaran)-Nya ialah Dia menciptakan pasangan-pasangan untukmu dari jenismu sendiri, agar kamu cenderung dan merasa tenteram kepadanya, dan Dia menjadikan diantaramu rasa kasih dan sayang. Sungguh, pada yang demikian itu benar-benar terdapat tanda-tanda (kebesaran Allab) bagi kaum yang berfikir. 6

Pernikahan adalah akad yang menghalalkan persetubuhan antara wanita dan laki-laki, disertai dengan kalimat-kalimat yang ditentukan. Dengan pernikahan tersebut, maka dibatasilah hak dan kewajiban keduanya, sesuai dengan ajaran Islam.7 Perkawinan akan sah apabila memenuhi syarat-syarat dan rukun nikah. Adapun rukun perkawinan ada lima, yaitu terdiri dari mempelai laki-laki, mempelai perempuan, wali, dua orang saksi, dan shigat ijab kabul.8 Adapun syarat perkawinan itu adalah hal yang menjadi penentu keberadaan sesuatu, dan ia berada di luar hakikat sesuatu tersebut. Syarat-syarat setiap akad ada empat, yaitu terdiri dari syarat pelaksanaan, syarat sah, syarat terlaksana, dan syarat kelanggengan.9

Menurut Undang-Undang No.1 Tahun 1974 tentang Perkawinan Pasal 6 ayat (2) mengisyaratkan usia yang matang dalam perkawinan adalah umur 21 tahun, di mana pasangan calon memepelai yang hendak melangsungkan perkawinan yang belum mencapai umur 21 tahun, harus mendapat izin kedua orang tua.10

Meski demikian, walaupun Undang-Undang telah membatasi usia perkawinan, tapi Undang-Undang sendiri telah memberikan

5 Mardani, Hukum Perkawinan Islam di Dunia Islam Modern (Yogyakarta: Graha Ilmu, 2011), 11.

6 Departemen Agama RI, Al-Qur'an dan Terjemahan..., 406.

7 LM Syarife, Membina Cinta Menuju Perkawinan..., 9.

8 H.M.A. Tihami dan Sohari Sahrani, Fikih Munakahat Kajian Fikih Nikah Lengkap(Jakarta: Rajawali Pers, 2010), 12.

9 Wahbah Az-Zuhaili, Fiqib Islam Wa Adillatubu Jilid 9, penerjemah, Abdul Hayyie al - Kattani (Depok: Gema Insani, 2011), 54.

10 Undang-undang Perkawinan No. 1 Tabun 1974 (Jakarta: Departemen Agama RI, 2002), 110. 
kemungkinan untuk melakukan perkawinan di bawah usia ketentuan tersebut, yaitu dengan memberikan dispensasi kawin melalui Pengadilan Agama bagi yang belum memasuki usia kawin. Hal ini diatur dalam Undang Undang No. 1 Tahun 1974 tentang Perkawinan Pasal 7 ayat (2).11

Di Indonesia, masalah perkawinan muda telah banyak terjadi, yang mana dibuktikan dalam Badan Pusat Statistik tahun 2017 menunjukkan bahwa angka perkawinan muda berada di atas $25 \%$ di 23 Provinsi dari 34 Provinsi yang disurvei.12 Kalau diperhatikan mengenai pelaksanaan pernikahan yang terjadi di masyarakat maka terkadang ditemui pasangan pengantin yang masih relatif muda. Masalah usia nikah ini merupakan salah satu faktor yang penting dalam persiapan pernikahan. Karena usia seseorang akan menjadi ukuran apakah ia sudah cukup dewasa atau belum dalam bersikap dan berbuat. Orang yang telah dewasa fisik dan mental belum tentu dapat membina rumah tangga secara sempurna, apalagi orang atau anak muda yang belum dewasa..

Pernikahan muda adalah pernikahan yang dilakukan remaja di bawah umur 20 tahun yang belum siap untuk melaksanakan pernikahan. Pernikahan tersebut terjadi karena disebabkan oleh faktor sosial, pendidikan, ekonomi, budaya, faktor orang tua, faktor diri sendiri dan tempat tinggal.13

Di Kabupaten Pasuruan, masih banyak terjadi pernikahan usia muda. Hal tersebut dapat dilihat pada laporan di Pengadilan Agama di Tahun 2015, yangmenunjukkan ada 110 pasangan yang meminta izin menikah ke Pengadilan Agama.14 Berdasarkan permasalahan ini Dinas Keluarga Berencana dan Pemberdayaan Perempuan

11 Ibid.,112.

12 Yusuf Hanafi, Kontroversi Perkawinan Anak di Bawah Umur (Chilid Marriege) Perspektif Fikih Islam, HAM Internasional, dan UU Nasional (Bandung: Cv. Mander Maju, 2011), 50.

13 Muhamad Iqbal, Psikologi Pernikaban Menyelami Rabasia Pernikaban..., 20.

14 Pemerintahan Kabupaten Pasuruan,'Inovasi MLM Genre Kabupaten Pasuruan Raih Penghargaan Top 25 Kovablik 2018”, dalam https://www.pasuruankab.go.id/berita-4571-inovasi-mlm-genre-kabupaten-

pasuruan-raih-penghargaan-top-25-kovablik-2018.html diakses pada 18 Desember 2018. 
Kabupaten Pasuruan memberikan solusi yang aplikatif dan komprehensif berupa program Multi Level Marketing Generasi Berencana (MLM Genre) yang dimulai sejak 2016. Program MLM Genre diharapkan bisa menjadi solusi atas banyaknya kasus pernikahan usia muda di Kabupaten Pasuruan.15

MLM Genre memiliki empat cara pendekatan kepada remaja yang memiliki kesadaran dan pemahaman yang rendah akan pentingnya menikah di usia yang telah ditetapkan. Keempat pendekatan tersebut diantaranya adalah Komunitas Genre yaitu pembentukan komunitas Genre di kecamatan, desa, dan dusun; Safari Genre yaitu, sosialisasi dan edukasi tiga resiko yang dihadapi oleh remaja terkait kesehatan reproduksi remaja yang meliputi seksualitas, merencanakan pernikahan dan keluarga, dan pernikahan usia dini; Hello Genre yaitu, saat sosialisasi terhadap program Genre, duta Genre memberikan kartu nama dan nomor telefon duta serta menyampaikan di media sosial; Salam Genre yaitu, melakukan pendekatan silaturahmi kepada remaja, jika ada kasus tertentu seperti pengaduan tentang kawin muda.16

Berdasarkan latar belakang di atas, maka perlu dikaji lebih dalam tentang pelaksanaan dari program Multi Level Marketing Generasi Berencana (MLM Genre) ditinjau dari maslahah mursalah maka saya memberi judul Analisis Maslahah Mursalah terhadap program Multi Level Marketing Generasi Berencana (MLM Genre) Dinas Keluarga Berencana dan Pemberdayaan Perempuan Kabupaten Pasuruan.

\section{Pengertian Maslahah Mursalah}

Maslahah mursalah menurut istilah terdiri dari dua kata yaitu Maslabah dan mursalah. Kata maslahah yang mengandung arti manfaat, dan kata mursalab berarti lepas. Gabungan dua kata tersebut yaitu Maslahah mursalah seperti yang dikemukakan Abdul Wahab Khalaf, berarti sesuatu yang dianggap maslahat namun tidak ada ketegasan hukum untuk merealisasikannya dan tidak pula ada dalil

15 Ibid.

16

SuaraPasuruan,"MLMGenreBerhasilTurunkanKasusPernikahanDinidiKabupate nPasuruan,dalamhttps://suarapasuruan.wordpress.com/2018/10/03/mlmgenre-berhasil-turunkan-kasus-pernikahan-dini-di-kabupaten-pasuruan/ diakses pada 30 November 2018. 
tertentu baik yang mendukung maupun yang menolaknya.17 Sedangkan Imam Malik menyebut kata maslahah mursalah yaitu kepentingan umum atau kesejahteraan masyarakat. Kata mursal dalam bahasa Arab, secra harfiah berarti kesejahteraan. Imam Ahmad ibn Hanbal menyebut maslahah mursalab ini dengan maksud mencari pemecahan yang terbaik bagi kepentingan umum.18

Mashalah bentuk jamak dari maslahah, yang mana berarti kemaslahatan, kepentingan. Mursalah berarti terlepas. Dengan begitu maslahah mursalah berarti kemaslahatan yang terlepas, penetapan hukum berdasarkan kepada manfaat bagi manusia atau menolak kemadaratan atas mereka.19

Secara terminologi, Maslahab adalah kemanfaatan yang dikehendaki Allah untuk hamba-hambanya, baik berupa pemeliharaan agama, jiwa atau diri mereka. Pemeliharaan kehormatan diri, keturunan mereka, akal budi mereka, maupun pemiliharaan harta kekayaan meraka.20

Maslahah mursalah yaitu suatu kemaslahatan yang tidak disinggung oleh syara' dan tidak pula terdapat dalil-dalil yang menyeluruh untuk mengerjakan atau meninggalkannya, sedangkan jika dikerjakan akan mendatangkan kebaikan yang besar atau kemaslahatan. Maslahah mursalah disebut juga maslahat yang mutlak. Karena tidak ada dalil yang mengakui kesahan atau kebatalannya. Jadi pembentuk hukum dengan cara maslahah mursalah semata-mata untuk mewujudkan kemaslahatan manusia dengan arti untuk mendatangkan manfaat dan menolak kemudaratan dan kerusakan bagi manusia. 21

Maslahah mursalah adalah menetapkan hukum suatu masalah yang tidak ada nash atau ijma' berdasarkan kemaslahatan. Suatu kebaikan yang tidak disinggung-singgung syara' untuk mengerjakan

17 Satria Effendi, Ushul Figh (Jakarta: Kencana, 2005), 148.

18 Rahman, Penjelasan Lengkap Hukum-Hukum Allah (SYARIAH), Jakarta: PT Raja Grafindo, 2002), 111.

19 Suparti dan Djedjen Zainuddin, Fikih (Semarang: PT Karya Toha Putra, 1994), 184.

20 Asmawi, Perbandingan Ushul Fiqh (Jakarta: Amzah, 2011), 128.

21 Ahmad Sanusi dan Sihari, Ushul Fiqh (Jakarta: Rajawali Perd, 2015), 79. 
atau meninggalkannya, tetapi kalau dikerjakan akan membawa manfaat atau menghindari keburukan.22

Memahami hakikat dari maslahah mursalah maka pengertian maslahah mursalab adalah sama dengan muthlaqah, yaitu terlepas. Maksudnya maslahat itu tidak ada dalil tertentu yang membenarkan maupun membatalkannya. Dalam kajian ushul fiqh, Maslabah mursalah (dalam bentuk mufrad) atau masalih mursalih (dalam bentuk jamak) saling digunakan silih berganti.23

Maslahah mursalah ialah yang mutak. Menurut istilah ahli ushul, kemaslahatan yang tidak disyariatkan oleh syari' dalam wujud hukum di dalam rangka menciptakan kemaslahatan, di samping tidak terdapat dalil yang membenarkan atau menyalahkan. Karenanya, maslahah itu disebut mutlak, lantaran tidak terdapat dalil yang menyatakan benar dan salah.24

Menurut Wahbah Zuhaili mengemukakan bahwa yang dimaksud dengan maslahah mursalah adalah beberapa sifat yang sejalan dengan tindakan dan tujuan syara', tetapi tidak ada dalil tertentu dari syara' yang membenarkan atau menggugurkan, dan dengan ditetapkan hukum padanya akan tercapai kemaslahatan dan tertolak kerusakan dari manusia.25

\section{Macam-Macam Maslahah}

Dilihat dari pembagian maslahah, maslahah dibedakan menjadi dua yaitu, dilihat dari segi tingkatannya dan eksistensinya.

1. Maslahab dilihat dari segi tingkatannya

a. Maslahab dharuriyyah

Maslabah dharuriyyah adalah perkara-perkara yang menjadi tempat tegaknya kehidupan manusia, yang ditinggalkan maka rusaknya kehidupan, timbullah fitnah, dan kehancuran yang hebat.26

22 Masykur Anhari, Ilmu Ushul Fiqih (Surabaya: Diantama, 2008), 101.

23 Abdul Manan, Reformasi Hukum Islam di Indonesia (Jakarta: Rajawali Press, 2013), 265.

24 Miftahul Arifin dan A. Faishal Haq, Ushul Fiqh: Kaidah-Kaidah Penetapan Hukum Islam (Surabaya: Citra Media, 1997), 142

25 Abdul Manan, Reformasi Hukum Islam di Indonesia..., 266

26 Khairul Umam, Ushul Fiqih I (Bandung: CV Pustaka Setia, 1998), 138. 
Maslabah dharuriyyah adalah kemaslahatan yang berhubungan dengan kebutuhan pokok manusia baik di dunia dan di akhirat. Kemaslahatan seperti ini ada lima yaitu: 1) memelihara agama, yang mana memeluk suatu agama merupakan fitrah dan naluri yang tidak dapat diingkari dan sangat dibutuhkan umat manusia. Maka dari itu Allah mensyariatkan agama yang wajib dipelihara setiap orang, baik yang berkaitan dengan akidah, ibadah, maupun muamalah. 2) memelihara jiwa, yang mana hak hidup juga merupakan hak paling asasi bagi setiap manusia untuk berusaha memeperoleh makanan, minuman, dan pakain untuk mempertahankan hidupnya. Begitu juga kewajiban mengqishash atau atau mendiat orang yang berbuat pidana. 3) memelihara akal, Allah menjadikan pemeliharaan akal itu sebagai suatu yang pokok. Dan kewajiban untuk meninggalkan minuman khamar dan segala sesuatu yang memabukkan serta menyiksa orang yang meminumnya. 4) memelihara keturunan, Allah mensyariatkan nikah dengan segala hak dan kewajiban yang diakibatkannya. Dan menghindarkan diri dari berbuat zina, begitu juga hukuman yang dikenakan kepada pelaku zina, laki-laki atau perempuan. 5) memelihara harta, harta merupakan sesuatu yang pokok dalam kehidupan manusia. Untuk mendapatkannya Allah mensyariatkan berbagai ketentuan dan untuk memelihara harta seseorang dan menjauhi pencurian, begitu juga memberikan hukuman kepada pencuri dan perampok. 27

b. Maslahah hajiyyah

Maslahah hajiyyah adalah kemaslahatan yang dibutuhkan dalam menyempurnakan kemaslahatan pokok sebelum yang berbentuk keringanan untuk mempertahankan dan memelihara kebututuhan mendasar manusia. Dalam hal ini memelihara kemerdekaan pribadi, kemerdekaan beragama. Dan melarang atau mengharamkan rampasan dan penodongan termasuk juga ke dalam lingkungan hajiyyah.28

27 Burhanudin, Fiqib Ibadah (Bandung: CV Pustaka Setia, 2001), 155-156.

28 Ibid, 156. 
Kemaslahatan hjizyah ini berlaku dalam lapangan ibadah, adat, muamalat, dan bidang jinayah. 1) dalam hal ibadah seperti qashar sholat, berbuka puasa bagi yang musafir. 2) dalam hal adat seperti diperbolehkannya berburu, memakan, memakai yang baik-baik dan yang indah-indah. 3)dalam dan muamalat seperti diperbolehkannya jual beli secara salam, dibolehkan talak untuk menghindari kemaslahatan dari suami istri. 4) dalam bidang jinayah seperti menolak hudud lantaran adalah kesamaan-kesamaan pada mereka.29

c. Maslahab tabsiniyyah

Maslabah tabsiniyyah adalah kemaslahatn umum yang menyangkut kepentingan orang banyak. Kemaslahtan umum itu tidak berarti untuk kepentingan semua orang, tetapi dapat berbentuk kepentingan mayoritas atau banyakan umat.30

Kemaslahatan tabsiniyyah masuk dalam lapangan ibadah, adat, muamalah, dan bidang uqubat. 1) dalam hal ibadah seperti, kewajiban bersuci dan menutup aurat, dan memakai pakain yang baik ketika shalat. 2) dalam hal adat seperti, menjaga adat makan, minum, memilih makan-makanan yang baik. 3) dalam hal muamalah seperti, larangan menjaul bendabenda yang najis, tidak memberikan sesuatu ke orang lain melebihi dari kebutuhannya. 4) dalam hal uqubat seperti, dilarang berbuat curang dalam timbangan ketika jual beli, dan dalam hal peperangan tidak boleh membunuh wanita, anakanak dan orang lanjut usia.31 Imam Abu Zahrah menambahkan, melarang wanita-wanita muslim keluar ke jalan-jalan umum memakai pakaian yang dan perhiasan yang mencolok. Sebab dapat menimbulkan fitnah serta dapat terjadi hal-hal yang tidak diinginkan.32

2. Maslahah dilihat dari segi eksistensinya

a. Maslahab mu'tabarah

29 Khairul Umam, Ushul Fiqib I..., 140.

30 Burhanudin, Faqib Ibadah..., 156.

31 Khairul Umam, Ushul Fiqih I..., 141.

32 Ibid, 154. 
Maslahah mu'tabarah, yaitu kemaslahatan yang didukung oleh syara', yang dimaksud adanya dalil khusus yang jadi dasar bentuk dan jenis kemaslahatan tersebut. Seperti; hukuman atas orang yang meminum-minuman keras dalam hadis Rasulullah SAW, dan diwajibkan hukuman qisas untuk peminum minuman keras demi untuk memelihara akal. Kemaslahatan seperti ini, menurut kesepakatan para ulama, dapat dijadikan landasan hukum.33

b. Maslahah mulgha

Maslahah mulgha, yaitu kemaslahatan yang ditolak oleh syara' karena bertentangan dengan ketentuan syara'. Maksudnya sesuatu yang dianggap maslahah oleh akal pikiran, tetapi dianggap palsu karena kenyataannya dianggap bertentangan dengan ketentuan syarat. Atau maslahah yang berlawanan dengan ketentuan nas. Seperti; anggapan bahwa menyamakan pembagian warisan antara laki-laki dan anak perempuan adalah maslahah, tetapi anggapan tersebut bertentangan dengan syariat. Pada ayat 11 surat An-Nisa'

"Allah mensyari'atkan bagimu tentang (pembagian pusaka untuk) anak-anakmu. Yaitu: bahagian seorang anak lelaki sama dengan bagabian dua orang anak perempuan dan jika anak itu semuanya perempuan lebih dari dua, maka bagi mereka dua pertiga dari harta yang ditinggalkan; jika anak perempuan itu seorang saja, maka ia memperoleh separuh harta. dan untuk dua orang ibu-bapak, bagi masing-masingnya seperenam dari harta yang ditinggalkan, jika yang meninggal itu mempunyai anak; jika orang yang meninggal tidak mempunyai anak dan ia diwarisi oleh ibu-bapaknya (saja), maka ibunya mendapat sepertiga; jika yang meninggal itu mempunyai beberapa saudara, mmaka ibunya mendapat seperenam. (Pembagian-pembagian tersebut di atas) sesudah dipenubi wasiat yang ia buat atau (dan) sesudah dibayar butangnya. (Tentang) orang tuamu dan anak-anakmu, kamu tidak mengetabui siapa di antara mereka yang lebih dekat (banyak) manfaatnya bagimu. Ini adalah ketetapan dari Allah. Sesungguhnya Allah Maha mengetahui lagi Maha Bijaksana."

33Burhanudin, Fiqib Ibadah..., 158. 
Ayat di atas menegaskan bahwa pembagian anak laki-laki dua kali pembagian anak perempuan. Dengan adanya pertentangan tersebut menunjukkan bahwa apa yang dianggap maslahat itu, bukan maslahat di sisi Allah. Dan tidak dapat dijadikan landasan hukum.34

c. Maslahab Mursalab

Maslahah mursalah, yaitu kemaslahatan yang keberadaanya tidak didukung syara' dan tidak pula dibatalkan atau ditolak syara' melalui dalil yang rinci.35 Maksudnya masalah-masalah yang tidak ada ketegasan hukumnya dan tidak pula ada bandingannya dalam Al-Qur'an dan Sunnah untuk dapat dilakukan analogi.36

Para Ulama menetapkan tiga syarat agar suatu kemaslahatan dapat dikategorikan sebagai maslahah yang dimaksud dalam maslahah mursalah. Tiga syarat tersebut anatara lain:

1) Kemaslahatan tersebut berupa kemaslahatan yang hakiki, bukan kemaslahatan yang semu. Artinya penetapan hukum syara' kenyataanya benar-benar menarik suatu manfaat atau menolak bahaya. Jika hanya didasarkan pada penetapan hukum itu mungkin menarik suatu manfaat, tanpa munculnya suatu bahaya, maka kemaslahatan tersebut bersifat semu.

2) Kemaslahatan tersebut merupakan kemaslahatan umum, bukan kemasahatan pribadi. Artinya bahwa penetapan hukum syara' itu dalam kenyataanya dapat menarik manfaat bagi mayoritas umat manusia atau menolak bahaya dari mereka, bukan bagi perseorangan ataupun bagi suatu kelompok.

3) Penetapan hukum kemaslahatan tersebut tidak boleh bertentangan dengan hukum atau dasar yang telah ditetapkan dengan nash atau ijma'. Seperti anggapan kemaslahatan tentang menyamakan bagian warisan anak laki-laki dengan anak perempuan. $\mathrm{Hal}$ ini jelas

34 Satria Efendi, Ushul Fiqh..., 149.

35 Burhanudin, Fikih Ibadah..., 159.

36 Satria Efendi, Ushul Fiqih..., 149. 
bertentangan dengan yang sudah ditetapkan dalam alQur'an bahwa bagian warisan anak laki-laki adalah dua kali dari bagian anak perempuan. 37

Maka dapat disimpulkan bahwa maslahah mursalah adalah metode untuk menetapkan hukum suatu perkara yang mana kemaslahatan dari perkara tersebut tidak ditunjuk ataupun ditolak al-Qur'an dan sunnah, dan kemaslahatan tersebut haruslah kemaslahatan yang mutlak, bersifat umum dan tidak bertentangan dengan hukum atau dasar yang telah ditetapkan oleh syari'.

3. Maslahah dilihat dari segi kandungan

a. Maslabah 'ammah

Maslahah 'ammah yaitu kemaslahatan umum yang menyangkut kepentingan banyak orang. Kemaslahatn umum itu tidak berarti untuk kepentingan semua orang, tetapi bisa berbentuk kepentingan mayoritas umat atau kebanyakan umat. Contohnya, para ulama membolehkan membunuh penyebar bid'ah yang dapat merusak 'aqidab umat, karena menyangkut kepentingan orang banyak.

b. Maslahah khassah

Maslahah khassah yaitu kemaslahatan abadi dan ini sangat jarang sekali, seperti kemaslahatan yang berkaitan dengan pemutusan hubungan perkawinan seseorang yang dinyatakan hilang (mafqud) pentingnya pembagian kedua kemaslahatan ini berkaitan dengan prioritas mana yang harus didahulukan apabila antara kemaslahatan umum bertentangan dengan kemaslahatan pribadi. Dalam pertentangan kedua kemaslahatan ini, islam mendahulukan kemaslahatan umum dari pada kemaslahatan pribadizs

\section{Maslahah Mursalah sebagai Metode Istinbat Hukum Islam}

Maslabah sebagai dalil hukum mengandung arti bahwa Maslabah menjadikan landasan tolak ukur dalam suatu penetapan hukum. Pada masalah tertentu ditetapkan hukum sedemikian rupa karena

37 Abdul Wahhab Khallaf, Ilmu Ushul Fikih Kaidah Hukum Islam Terjemah oleh Faiz. el Muttaqin (Jakarta: Pustaka Amani, 2003).

38 Nasrun Haroen, Ushul Fiqh I, (Jakarta: Logas Wacana Ilmu, 1997), 117. 
kemaslahatan menghendaki agar hukum tersebut ditetapkan pada masalah tersebut.

Secara garis besar dijelaskan ulama ushuliyyun membahas maslahah dalam dua pokok bahasan yaitu, pertama, ketika membahas kajian seputar maslabah sebagai al-íllah (motif yang melahirkan hukum, dan yang kedua, Maslabah sebagai dalil penetapan hukum. Dalam pembahasan al-illah ini berkaitan dengan pembahasan seputar masalah qiyas (analogi), yaitu mempersamakan hukum suatu masalah yang tidak ada nashnya dengan hukum masalah yang ada nashnya karena di antara keduanya terdapat kesamaan dari segi 'illah. Mayoritas jumhur ulama berpendapat setiap hukum yang ditetapkan oleh nash atau ijma' didasarkan atas hikmah dalam bentuk meraih manfaat atau kemaslahatan dan menghindarkan mafsadah. Dalam hal itu setiap 'illah yang menjadi landasan suatu hukum bermuara pada kepentingan kemaslahatan manusia. Dan mereka percaya bahwa tidak satu pun ketetapan hukum yang ditetapkan oleh nash yang di dalamnya tidak terdapat kemaslahatan manusia, baik kemaslahatan di dunia maupun di akhirat. 39

Perbedaan pendapat ulama mengenai maslahah mursalah para ulama ushul fiqih sepakat bahwa maslahah mursalab tidak sah menjadi landasan hukum dalam bidang ibadah. Karena bidang ibadah harus diamalkan sebagaimana adanya diwariskan oleh Rasulullah, dan oleh karena itu bidang ibadah tidak berkembang. Mereka juga berbeda pendapat dalam bidang muamalah.

Berdasarkan alasan-alasan diatas golongan Malikiyah, Hanabilah, dan sebagian dari golongan Syafi'iyah menganggap sah maslahah mursalah sebagai landasan hukum. Dengan adanya alasanalasan yang dikemukakan oleh pihak yang menolak Maslabah mursalab sebagai dalil hukum, saya kira lemah. Karena kenyataannya berlawanan dengan dalil tersebut, yang mana tidak semua kebutuhan manusia, terperinci dalam al-Qur'an dan Sunnah. Di samping itu, untuk menetapkan suatu maslahah mursalah itu secara sah dapat difungsikan, membutuhkan beberapa persyaratan yang ekstra ketat. Dengan adanya persyaratan-peryaratan tersebut, diharapkan tidak adanya penyalahgunaan di dalamnya.

39 Abd Rahman Dahlan, Ushul Figh (Jakarta: Amzah, 2010), 315. 
Abd al-Wahab Khalaf dan Abu Zahrah memberikan persyaratan-persyaratan penggunaan maslahah mursalah, yang disimpulkan sebagai berikut:

1. Maslabah mursalab tidak boleh bertentangan dengan maqasid alsyariah, dalil-dalil kulli, dalil-dalil juz'i yang qath'iyyah dan dalalahnya.

2. Kemaslahatan tersebut harus meyakinkan, maksudnya harus ada pembahasan yang rasional serta mendalam sehingga kita yakin bahwa hal tersebut memberikan manfaat atau menolak kemadharatan.

3. Kemaslahatan tersebut bersifat umum.

4. Pelaksanaanya tidak menimbulkan kesulitan yang tidak wajar.40

Selain itu Zaky ad-Din Sya'ban juga menyebutkan ada empat syarat yang harus diperhatikan bila menggunakan maslabah mursalah dalam menetapkan hukum, yaitu:

1. Mashlabhah mursalah adalah maslahah yang hakiki dan bersifat umum, dalam arti dapat diterima oleh akal sehat dan benarbenar mendatangkan manfaat bagi manusia.

2. Benar-benar sejalan dengan maksud dan tujuan hukum syara' dalam menetapkan setiap hukum, yaitu mewujudkan kemaslahatan bagi umat manusia.

3. Benar-benar sejalan dengan tujuan syara' dalam menetapkan hukum, tidak berbenturan dengan dalil syara' yang telah ada, baik dalam bentuk al-Qur'an dan Sunnah, maupun ijma' Ulama terdahulu.

4. Maslahah mursalah itu diamalkan dalam keadaan yang mana akan berada dalam suatu kesempitan hidup, dengan arti harus ditempuh untuk menghindarkan dari kesulitan.41

Adapan kehujjahan maslabah mursalah, pada dasarnya Jumhur Ulama menerima sebagai salah satu alasan dalam menetapkan hukum syara', meski dalam penerapannya dan penempatan syaratnya mereka memilki beda pendapat. Jumhur ulama berpendapat bahwa kemaslahatan manusia itu selalu berubah baik karena waktu maupun

40 A. Djazuli, Ilmu Fiqih Penggalian, Perkembangan, dan Penerapan Hukum Islam (Jakarta: Prenadamedia Group, 2005), 87.

41 Abdul Manan, Reformasi Hukum Islam di Indonesia..., 269. 
tempat, maka dari itu untuk mewujudkan hal itu setiap hal yang mendatangkan kebaikan harus diwujudkan, dan apabila tidak demikian maka kemaslahatan tidak akan pernah terwujud dan tentu hal ini tidak sesuai dengan tujuan syariah Islam.

Selain itu sejarah membuktikan bahwa para sahabat, tabiin, para mujtahid dengan jelas telah membentuk hukum berdasarkan pertimbangan maslahah mursalah. Seperti; Abu Bakar Shiddiw melalui pendekatan maslahah mursalah menghimpun lembaran-lembaran bertuliskan ayat-ayat al-Qur'an yang berserakan menjadi satu mushaf. Semula Abu Bakar ragu menggunakan pendekatan ini, tetap atas saran dan desakan Umar bahwa penghimpunan al-Qur'an ke dalam satu mushaf akan banyak mendatangkan kemaslahatan kepada umat Islam, maka Abu Bakar pun akhirnya memenuhi saran tersebut, Umar bin Khattab yang menetapkan kewajiban pajak dan membuat penjara, kelompok Shafi'iy yang mewajibkan qisas yang dilakukan oleh banyak orang kepada satu orang.42

\section{Profil Singkat Dinas Keluarga Berencana dan Pemberdayaan Perempuan Kabupaten Pasuruan}

Kantor Dinas Keluarga Berencana dan Pemberdayaan Perempuan berdiri di Pasuruan, yang mana berada di Jl. Hassannudin No 15 Kabupaten Pasuruan. Yang mana diresmikan oleh Gubernur JATIM dan Bupati Pasuruan, serta didampingi oleh Kapolda Jatim pada tanggal 20 Oktober 1990.43

Kantor Dinas Keluarga Berencana dan Pemberdayaan Perempuan di Kabupaten Pasuruan yang telah ditetapkan dengan peraturan Bupati Pasuruan Nomor 25 Tahun 2016 tentang kedudukan, susunan organisasi, tugas dan fungsi serta tata kerja Dinas Keluarga Berencana dan Pemberdayaan Perempuan Kabupaten Pasuruan yang dipimpin oleh Kepala Dinas yang penyelenggaraanya dituangkan sesuai tugas, fungsi, dan struktur organisasi.

42 Sapiudin Shidiq, Usbul Fiqih (Jakarta: Prenadamedia Group, 2011), 91.

43 Dokumen Kantor Dinas Keluarga Berencana dan Pemberdayaan Perempuan Kabupaten Pasuruan. 
1. Visi dan Misi Keluarga Berencana dan Pemberdayaan Perempuan Kabupaten Pasuruan44

a. Visi:

"Menuju Kabupaten Pasuruan yang sejahtera, maslahat, dan berdaya saing"

b. Misi:

"Meningkatkan pelayanan dasar terutama pelayanan kesehatan permukiman dan pendidikan dengan mengintegritaskan pendidikan formal sebagai wujud afimasi pendidikan karakter di kabupaten pasuruan"

2. Tugas Pokok dan Fungsi Keluarga Berencana dan Pemberdayaan Perempuan Kabupaten Pasuruan45

a. Tugas Pokok

Membantu Bupati melaksanakan urusan pemerintahan yang menjadi kewenangan pemerintah daerah di bidang pengendalian penduduk dan keluarga berencana serta bidang pemberdayaan perempuan dan perlindungan anak serta tugas pembantuan.

b. Fungsi

1) Perumusan kebijakan di bidang pengendalian penduduk dan keluarga berencana serta bidang pemberdayaan perempuan dan perlindungan anak.

2) Pelaksanaan kebijakan di bidang pengendalian penduduk dan keluarga berencana serta bidang pemberdayaan perempuan dan perlindungan anak.

3) Pelaksanaan evaluasi di bidang pengendalian penduduk dan keluarga berencana serta bidang pemberdayaan perempuan dan perlindungan anak.

4) Pelaksanaa administrasi di bidang pengendelaian penduduk dan keluarga berencana serta bidang pemberdayaan perempuan dan perlindungan anak.

5) Pelaksanaan fungsi lain yang diberikan oleh Bupati terkait dengan tugas dan fungsinya. 46

44 Ibid.

45 Ibid.

46 Dokumen Kantor Dinas Keluarga Berencana dan Pemberdayaan Perempuan Kabupaten Pasuruan 


\section{Program Multi Level Marketing Generasi Berencana (MLM Genre) oleh Dinas Keluarga Berencana dan Pemberdayaan Perempuan di Kabupaten Pasuruan}

Pembentukan Program Multi Level Marketing Generasi Berencana (MLM Genre) didasarkan pada:

a. Undang-undang No. 25 tahun 2004 tentang Sistem Perencanaan Pembangunan Nasional

b. Undang-undang No. 52 tahun 2009 tentang perkembangan Kependudukan dan Pembangunan Keluarga

c. Peraturan pemerintah No. 21 tahun 1994 tentang penyelenggaraan Pembangunan Keluarga Sejahtera

d. Peraturan Bupati Pasuruan No. 52 tahun 2016 tentang kedudukan, susunan organisasi, tugas dan fungsi serta tata kerja dinas keluarga berencana dan pemberdayaan perempuan kabupaten pasuruan

Undang-Undang No. 52 tahun 2009 tentang perkembangan kependudukan dan pembangunan keluarga berencana memerintahkan perlunya pengendalian kuantitas, peningkatan kualitas, dan pengarahan penduduk agar mampu menjadi sumber daya yang tangguh. Salah satu faktor yang mempengaruhi tingkat kelahiran penduduk adalah usia pernikahan muda.47

MLM Genre adalah sebuah terobosan dalam hal menurunkan jumlah kasus pernikahan dini yang digagas oleh Dinas Keluarga Berencana dan Pemberdayaan Perempuan di Kabupaten Pasuruan. Program ini merupakan program dari Dinas Keluarga Berencana dan Pemberdayaan Perempuan Kabupaten Pasuruan, yang mana program tersebut kemudian diterapkan di setiap Kecamatan yang ada di Kabupaten Pasuruan yang sejumlah 24 Kecamatan. Sasaran dari adanya program tersebut yaitu remaja 10-24 tahun dan belum menikah, mahasiswa/mahasiswi belum menikah, keluarga yang punya remaja, masyarakat peduli remaja.

Program ini lahir pada tahun 2016, karena pada tahun 2015 angka kasus pernikahan dini meningkat menjadi 110 kasus, yang

47 Yetti Purwaningsih, Wawancara, Pasuruan, 23 April 2019. 
kemudian pada tahun 2016 menjadi 120, di tahun 2017 menurun menjadi 80, dan di tahun 2018 menurun menjadi 41.48

Rekapitulasi data tersebut bersumber dari data laporan tahunan Kantor Dinas KBPP Kabupaten Pasuruan. Tingginya angka kasus pernikahan dini pada tahun 2015 tersebut membuat para staf Dinas KBPP untuk membuat inisiatif menanggulangi angka pernikahan tersebut.49

Pembentukan MLM Genre dilatarbelakangi oleh beberapa hal sebagai berikut:50

1. Semakin banyaknya kasus pernikahan usia dini

2. Kurangnya kesadaran masyarakat khususnya remaja untuk terlibat aktif mencegah pernikahan usia dini.

3. Semakin banyaknya kasus kehamilan yang tidak diinginkan

4. Bagi masyarakat yang tinggal diwilayah pedesaan khusunya Kecamatan Bangil, Masih melekatnya budaya masyarakat yang menganggap perempuan harus segera menikah, agar tidak dianggap sebagai perawan tua, menghindari zina, sebagai bagian dari agama untuk mensegerakan menikah.

Program MLM Genre ditujukan sebagai jawaban atas semakin maraknya kasus pernikahan dini di Kabupaten Pasuruan. Khususnya bagi para orang tua yang masih menganggap bahwa anak perempuan kalau belum menikah di atas 20 tahun bakal jadi perawan tua, pemikiran inilah yang ingin diubah.51 MLM Genre ini menjadi upaya penanganan yang komprehensif melalui pendekatan, silaturrahmi, dan pendampingan kepada keluarga yang akan menikahkan remaja di bawah umur atau terlanjur menikah dini dengan melibatkan koordinasi penyuluh $\mathrm{KB}$, tokoh agama, tokoh masyarakat, dan petugas kesehatan.52

Inovasi program MLM Genre merupakan sistem yang sederhana akan tetapi unik dan aplikatif, sehingga mampu

48 Putri Nurmalitasari, Wawancara, Pasuruan, 4 Mei 2019.

49 Dokumen Dinas Keluarga Berencana dan Pemberdayaan Perempuan Kabupaten Pasuruan.

50 Kokok Adi Prayogo, Wawancara, Pasuruan, 23 April 2019.

51 Ibid.

52 Ibid. 
menggurangi kasus pernikahan dini pada remaja. Di samping itu, inovasi ini tidak membutuhkan biaya besar, akan tetapi dapat memberikan dampak yang besar. 53

Dalam pelaksanaan Multi Level Maketing Generasi Berencana (MLM Genre) dinas KBPP melibatkan banyak pihak, mulai dari penyuluh KB, BKKBN, Dinas Kesehatan, Dinas pendidikan, Kecamatan, hingga kantor KUA.

Multi Level Maketing Generasi Berencana (MLM Genre) memiliki empat pendekatan kepada remaja yang memiliki kesadaran dan pemahaman yang rendahakan pentingnya menikah di usia yang telah ditetapkan, keempat pendekatan tersebut sebagai berikut:54

1. Komunitas Genre

Komunitas Genre adalah suatu pembentukan kelompok remaja dari tingkat Kecamatan, Desa ataupun Dusun yang dinamai dengan Komunitas Genre yang mana kelompok tersebut dapat dari berbagai kalangan remaja seperti anak pramuka, saka kencana, pondok pesantren, ataupun dari komunitas-komunitas lainnya.

Kelompok remaja tersebut berkisar usia 10-24 tahun dan belum menikah, yang memiliki komitmen dan mampu memberikan dampak positif bagi remaja yang lainnya. Dan untuk saat ini yang sudah mengikuti komunitas Genre ada sekitar 240 anak yang terdiri dari 24 Kecamatan di Kabupaten Pasuruan

Dalam Komunitas Genre, remaja-remaja tersebut menyatakan ikrar tertulis maupun surat pernyataan untuk tidak menikah sampai di usia 20 tahun untuk perempuan dan 25 tahun untuk laki-laki. Mereka diberikan pelatihan atau bimbingan mengenai permasalahan remaja meliputi, tidak melakukan pernikahan diusia muda, tidak melakukan seks sebelum menikah, dan bagaimana mewujudkan keluarga yang samawa. Materimateri tersebut disampaikan pada pertemuan setiap satu bulan sekali. Selain pertemuan satu bulan sekali, komunitas Genre juga sering mengadakan event-event lainnya seperti lomba pembuatan film dokumenter tentang pernikahan dini.

53 Ibid.

54 Kokok Adi Prayogo, Wawancara, Pasuruan, 23 April 2019. 
Fajrina Maulidina 20 tahun, dari Kecamatan Beji sebagai anggota Komunitas Genre mengatakan: "dengan adanya program MLM Genre sangat memberikan dampak positif terhadap para remaja di Kabupaten Pasuruan, karena dalam salah satu pelaksanaanya dibentuklah Komunitas Genre yang mana dia memberikan materi-materi mengenai resiko jika melakukan pernikahan dini, selain itu materi yang disampaikan juga mengenai bagaimana cara membentuk keluarga yang sejahtera juga. Sayangnya dalam program ini belum maksimal berjalan di tiap-tiap Kecamatan, karena saya yang berasal dari Kecamatan Beji harus mengikuti Komunitas Genre ini di Kecamatan Bangil, karena di Kecamatan Beji belum terlaksananya program tersebut." 55

Muizzul 20 tahun, dari Kecamatan Bangil sebagai anggota Komunitas Genre mengatakan: "Saya sudah bergabung di Komuitas Genre ini sekitar 6 bulan yang lalu, dan saya tau adanya Program tersebut dari teman main saya. Saya setuju sekali dengan adanya program ini dapat menurunkan angka pernikahan muda di Kabupaten Pasuruan, selain itu di komunitas ini diberikan bekal bagaimana kalau kita menikah muda seperti resikonya, bagaimana merencanakan pernikahan dan keluarga, juga diberikan bekal bagai membentuk keluarga yang baik nanti jika kita menikah. Selain itu di komuitas ini juga menmbah teman baru saya, saya mendapatkan ilmu baru dan pengalaman baru karena dikomunitas ini banyak dari kalangan mbk, mulai dari yang masih sekolah, yang masih kuliah, ada juga yang sudah bekerja. Penyampaianya materi sendiri tidak formal sekali, kadang kita juga outbond di luar sambil sering-sering juga. Sayangnya untuk saat ini masih berjalan di 5 kecamatan saja, belum disemua kecamatan.56

2. Safari Genre

Safari Genre adalah sosialisasi atau edukasi yang dilakukan di sekolah-sekolah, komunitas, ataupun kelompok-kelompok remaja. Sosialilasi tersebut menyampaikan permasalahn remaja 3

55 Fajrina Maulidina, Wawancara, Pasuruan, 25 April 2019.

56 Muizzul, Wawancara, Pasuruan, 25 April 2019 
resiko Kesehatan Reproduksi Remaja (TRIAD KRR), yang meliputi tidak melakukan pernikahan diusia muda, tidak melakukan seks sebelum menikah, dan mewujudkan kelurga samawa.

Selain melakukan sosialisasi langsung ke sekolah-sekolah, komunitas, atau kelompok remaja, mereka juga memberikan sosialisasi melalui media sosial seperti di Instagram. Sosialisasi tersebut dilakukan oleh Duta Genre dan Ketua Pusat Informasi dan Konseling Remaja/Mahasiswa (PIK R/M)

3. Hello Genre

Hello Genre adalah memberikan kartu nama dan nomor telfon ke sekolah-sekolah, remaja, komunitas remaja saat dilakukanya Safari Genre. Jika membutuhkan konseling dan edukasi 3 resiko Kesehatan Reproduksi Remaja (TRIAD KRR), atau pelaporan pernikahan dini yang sudah terjadi untuk dilakukan deteksi dini pernikahan usia dini, maka dapat menghubungi nomor tersebut.

4. Salam Genre

Salam Genre adalah melakukan pendekatan silaturahmi kepada remaja, jika ada kasus tertentu seperti pengaduan tentang kawin muda. Serta melakukan konseling dan pendampingan secara komprehensif yang dilakukan oleh Dinas KBPP.

Materi - materi Program Multi Level Marketin Generasi Berencana (MLM Genre) adalah:

\section{Masa menunda perkawinan dan kehamilan57}

Kelahiran anak yang baik adalah apabila dilahirkan oleh ibunya yang telah berusia 20 tahun. Kelahiran anak yang dilahirkan oleh ibu yang berusia dibawah 20 tahun akan dapat mempengaruhi kesehatan ibu dan anak. Maka dari itu sangat dianjurkan apabila seorang perempuan belum berusia 20 tahun untuk menunda perkawinannya. Jika sudah terlanjur menjadi pasangan suami istri yang masih dibawah usia 20 tahun, maka dianjurkan untuk menunda kehamilan, dengan menggunakan alat kontrasepsi.

57 Dokumen Dinas Keluarga Berencana dan Pemberdayaan Perempuan Kabupaten Pasuruan 
Beberapa alasan medis dari perlunya penundaan usia kawin pertama dan kehamilan pertama bagi istri yang belum berumur 20 tahun adalah sebagai berikut:

a. Kondisi rahim dan panggul belum berkembang optimal sehingga dapat mengakibatkan resiko kesakitan dan kematian pada saat persalinan, nifas serta bayinya.

b. Kemungkinan timbul resiko medis seperti:

1) Keguguran

2) Preeklamsia (tekanan darah tinggi, cedema, proteinuria)

3) Eklamse (keracunan kehamilan)

4) Timbulnya kesulitan persalinan

5) Bayi lahir rendah (BBLR)

6) Bayi lahir sebelum pada waktunya

7) Kanker leher rahim

2. Seks Pra Nikah

Salah satu perilaku remaja yang dapat menimbulkan masalah bagi kesehatan remaja adalah perilaku hubungan seksual pra nikah. Hubungan seksual pranikah adalah kontak seksual yang dilakukan remaja dengan lawan jenis atau teman sesama jenis tanpa ikatan pernikahan yang sah.

Perilaku hubungan seksual pra nikah dapat menyebabkan berbagai masalah kesehatan, sosial dan ekonomi bagi remaja itu sendiri maupun keluarganya. Beberapa dampak dari hubungan seksual pranikah, antara lain:

a. Kehamilan tidak diinginkan

Kehamilan yang oleh karena suatu sebab maka keberadaanya tidak diinginkan atau diharapkan oleh calon orang tua bayi.

Kehamilan yang tidak diinginkan pada remaja terjadi karena ketidaktahuan atau minimnya pengetahuan tentang perilaku seksual yang dapat menyebabkan kehamilan, atau akibat pemerkosaan.

Dampak akibat kehamilan yang tidak diinginkan sebagai berikut:

1) Dampak fisik, antara lain status kesehatan fisik rendah, pendarahan, komplikasi dan kehamilan yang bermasalah. 
2) Dampak psikologis, antara lain tidak percaya diri, stress, malu.

3) Dampak social, antara lain prestasi sekolah rendah atau drop out dari sekolah, penolakan atau pengusiran oleh keluarga, dikucilkan oleh masyarakat, tingkat ketergantungan keuangan yang tinggi bahkan kemiskinan.

4) Dampak bagi anak yang dilahirkan, anak yang dilahirkan oleh ibu di usia remaja akan mengalami status kesehatan yang rendah, keterlambatan perkembangan intelektualitas dan masalah sosial lainnya.

b. Aborsi58

Aborsi adalah berakhirnya atau gugurnya kehamilan sebelum kandungan mencapai usia 20 minggu,yaitu sebelum janin dapat hidup di luar kandungan secara mandiri. Tindakan aborsi mengandung resiko yang cukup tinggi, apabila dilakukan tidak sesuai standar profesi medis. Kehamilan yang disebabkan oleh hubungan seksual pranikah dapat menyebabkan aborsi spontan atau aborsi buatan pada remaja.Beberapa alasan remaja melakukan aborsi sebagai berikut:

1) Ingin terus melanjutkan sekolah atau kuliah.

2) Takut pada kemarahan orang tua

3) Belum siap secara mental dan ekonomi untuk menikah dan mempunyai anak.

4) Malu pada lingkungan sosial bila ketahuan sebelum nikah.

5) Ingin terus bekerja.

Aborsi sangat berbahaya bagi kesehatan dan keselamatan remaja, karena memiliki beberapa dampak sebagai berikut:

1) Dampak fisik, seperti pendarahan yang terus menerus, infeksi alat repsoduksi karena kuretasi yang tidak steril, resiko rahim robek akibat kuretasi atau terbentuknya suatu saluran antara genital dan saluran kencing atau anus.

2) Dampak psikologis, seperti perasaan berdosa atau bersalah.

58 Ibid. 
3) Dampak sosial, seperti dikucilkan oleh masyarakat, teman dan keluarga

3. Merencanakan pernikahan dan keluarga59

a. Persiapan menikah

Alangkah lebih baiknya bila rencana pernikahan dan berkeluarga benar-benar disiapkan sebelumnya, agar hasilnya bukan hanya sekedar mengalir saja melainkan berkualitas dan harmonis. Yang perlu dipersiapkan:

1) Kenalilah calon suami/istri anda sebaik-baiknya sebelum menikah. Jangan menunggu sampai sudah menikah.

2) Berkomunikasi secara terbuka untuk saling mengenal kekuatan dan kelemahan, agar masing-masing siap menghadapinya.

3) Bacalah dan pelajari hal-hal berkaitan dengan persiapan berkeluarga dan kehidupan berkeluarga.

4) Carilah dan ikutilah kursus persiapan calon pengantin sebelum menikah.

5) Bicarakan dan ajukan pertanyanyaan mengenai kehidupan berkeluarga pada kedua orang tua.

6) Jauh-jauh hari sudah menabung untuk menyicil tempat tinggal, membayar keperluan anak, dan tabungan pendidikan bagi anak.

7) Rencanakan dengan baik kehamilan dan jumlah anak demi menjaga kualitas hidup anak.

b. Jumlah dan kualitas anak

Masih perlu persiapan-persiapan lain seperti kondisi fisik yang baik, kedewasaan dan tanggungjawab merawat bayi dan anak secara optimal, mengelola waktu dan kesibukan kerja, mengatur rumah agar aman bagi bayi dan anak-anak.

Jumlah anak sebaiknya direncanakan dengan baik. Perencanaan ini perlu dilakukan agar setiap anak yang dilahirkan mendapat kasih sayang, perawatan, dan perlindungan yang optimal. Anak yang lahir tanpa diinginkan, ada resiko ia kekurungan kasih sayang dan perlindungan yang

59 Ibid. 
optimal. Kekurangan perhatian di masa anak-anak dapat berdampak buruk sampai remaja dan dewasa.

c. Fungsi keluarga

Remaja yang akan berkeluarga mempelajari dulu apa sebenarnya fungsi keluarga itu:

1. Fungsi agama

Keluarga adalah wahana pembinaan kehidupan beragama, toleransi beragama.

2. Fungsi sosial budaya

Keluarga adalah wahana pembinaan dan persamaian nilai-nilai luhur budaya.

3. Fungsi cinta kasih

Keluarga harus menjadi tempat untuk menciptakan suasana cinta dan kasih sayang, menjaga komitmen.

4. Fungsi perlindungan

Keluarga merupakan wahana terciptanya suasana aman, nyaman, damai, dan adil dalam menghadapi segala tantangan.

5. Fungsi reproduksi

Diharapkan setiap anggota keluarga memahami cara hidup sehat dan mengerti tentang kesehatan reproduksinya.

6. Fungsi pendidikan

Keluarga adalah wahana terbaik dalam proses sosialisasi dan pendidikan, dan fondasi untuk perkembangan anak.

7. Fungsi ekonomi

Keluarga adalah tempat membina kualitas kehidupan ekonomi dan kesejahteraan keluarga, menambah kesejahteraan keluarga.

8. Fungsi lingkungan

Keluarga adalah wahana untuk menciptakan anggota keluarga yang mampu hidup harmonis.

\section{Analisis Maslahah Mursalah terhadap Program Multi Level Marketing Generasi Berencana dan Pemberdayaan Perempuan di Kabupaten Pasuruan}


Program Multi Level Marketing Generasi Berencana (MLM Genre) adalah sebuah program yang diselenggarakan oleh Dinas Keluarga Berencana dan Pemberdayaan Perempuan Kabupaten Pasuruan untuk mengurangi kasus pernikahan usia muda di Kabupaten Pasuruan. Dalam program ini diselenggarakan oleh tiaptiap kecamatan yang ada di Kabupaten Pasuruan, yang mana sejumlah 24 Kecamatan, namun dalam penerapan program MLM Genre untuk saat ini masih ada 5 kecamatan yaitu terdiri dari; Kecamatan Bangil, Kecamatan Kraton, Kecamatan Lekok, Kecamatan Pohjentrek, dan Kecamatan Nguling. Dalam program Multi Level Marketing Generasai Berencana (MLM Genre) Dinas Keluarga Berencana dan Pemberdayaan perempuan bekerja sama dengan beberapa pihak seperti, penyuluh $\mathrm{KB}$, tokoh agama, tokoh masyarakat, dan petugas kesehatan.

Pelaksanaan program MLM Genre yang pertama, Komunitas Genre adalah berupa pembentukan kelompok remaja dari tingkat Kecamatan, Desa ataupun Dusun, dalam komunitas Genre setiap remaja harus menyatakan ikrar tertulis untuk tidak menikah sampai di usia 20 tahun untuk perempuan dan 25 tahun untuk laki-laki. Dan dalam Komunitas Genre remaja-remaja tersebut diberikan pelatihan atau bimbingan mengenai permaslahan remaja seperti, tidak melakukan pernikahan usia muda, tidak melakukan seks sebelum menikah, dan merencanakan pernikahan dan keluarga.Kedua, Safari Genre adalah sosialisasi yang dilakukan di sekolah-sekolah, komunitas, atau kelompok-kelompik remaja, dan sosialisasi di media social seperti Instagram. Yang mana dalam sosialisasi tersebut menyampaikan permaslahan remaja yang biasa disebut TRIAD KRR resiko Kesehatan Reproduksi Remaja yang meliputi tidak melakukan pernikahan diusia muda, tidak melakukan seks sebelum menikah, danmerencanakan pernikahan dan keluarga. Ketiga, Hello Genre adalah memberi kartu nama dan no tlfn jika membutuhkan konseling, edukasi, atau pelaporan pernikahan dini yang sudah terjadi untuk dilakukan deteksi pernikahan usia dini, maka dapat menghubungi no tersebut. Keempat, Salam Genre adalah melakukan pendekatan silaturahmi kepada remaja, dan jika ada kasus pengaduan tentang kawin muda. Serta melakukan konseling dan 
pendampingan secara komprehensif yang dilakukan oleh Dinas Keluarga Berencana.

Program MLM Genre yang digagas oleh Dinas Keluarga Berencana dan Pemberdayaan Perempuan Kabupaten Pasuruan yang bertujuan untuk mengurangi pernikahan usia muda di Kabupaten Pasuruan. Dengan adanya program MLM Genre dapat menurukan angka pernikahan usia muda, serta bagi para remaja yang mengikuti program MLM Genre mendapatkan bekal untuk pernikahan yang akan datang, serta dapat mengetahui resiko jika melakukan pernikahan diusia muda. Sehingga mereka dapat mempertimbangkan berbagai aspek dalam hal kehidupan berkeluarga, kesiapan fisik, mental, emosional, pendidikan, sosial, dan ekonomi.

Materi yang disampaikan pada program MLM Genre ini antara lain: Masa menunda perkawinan dan kehamilan, seks pra nikah, merencanakan pernikahan dan keluarga. Ketiga materi tersebut sangat penting bagi remaja saat ini dalam membentuk generasi bangsa yang berkualitas karena tidak memandang dari satu sudut saja, tetapi juga memandang sudut yang lain baik dari sudut pandang agama, psikologi, maupun kesehatan.

Materi pertama, tentang masa menda perkawinan dan kehamilan ini mengupas tentang beberapa alasan medis dari perlunya penundaan usia menikah dan kehamilan bagi istri yang belum berusia 20 tahun. Sehingga mereka bisa mengetahui dan mencegah resiko yang akan timbul dikemudian hari jika melakukan pernikahan diusia muda.

Materi kedua, tentang seks pra nikah. Dalam materi ini dijelaskan mengenai masalah yang ditimbulkan jika melakukan seks pra nikah, dan dampak yang dapat ditimbukan jika melakukan seks pra nikah. Dalam materi ini juga dijelaskan kesehatan reproduksi. Dari materi yang disampaikan dapat mencegah timbulnya hal-hal yang tidak diinginkan seperti terjadinya aborsi, dan kehamilan yang tidak diinginkan serta menjaga kesehatan reproduksi mereka.

Materi ketiga. Tentang merencanakan pernikahan dan keluarga. Dalam materi ini mereka dijelaskan mengenai persiapan menikah yang diperlukan apa saja, jumlah dan kualitas anak, dan fungsi 
keluarga guna untuk mewujudkan keluarga yang sakinah mawaddah wa rahmah dan bahagia.

Materi Program MLM Genre Kabupaten Pasuruan tersebut memberikan manfaat kepada anggota yang mengikuti Komunitas Genre ataupun remaja-remaja lainnya. Dengan diberikannya contoh kasus kepada remaja jika mereka melakukan menikah dini, seks pra nikah, dan merencanakan pernikahan dan keluarga, menjadikan para remaja mendapatkan pengetahuan seputar pernikahan dan bisa membentuk kualitas keluarga yang sakinah mawaddah wa rahmah, dan membentuk penerus bangsa yang berkualitas.

Dalam perspektif maslahah mursalah, pelaksanaan program MLM Genre yang diselengarakan oleh Dinas Keluarga Berencana dan Pemberdayaan Perempuan Kabupaten Pasuruan, dibahas dalam beberapa segi:

Pertama, pelaksanaan program MLM Genre yang diselengarakan oleh Dinas Keluarga Berencana dan Pemberdayaan Perempuan dengan memberikan materi mengenai resiko pernikahan di usia muda, kesehatan reproduksi, bahaya penggunaan narkotika, alkohol, dan psikotropika sebagai mewujudkan ketahanan keluarga dan penerus bangsa yang berkualitas, telah sesuai dengan maslabah mursalah sebagai metode istinbath karena tidak ada dalil secara tegas yang menjelaskan suatu persoalan yang dikaji, baik dari al-Quran dan al-Sunnah.

Kedua, berkaitan dengan syarat maslahah mursalah bahwa kemaslahatan tersebut sejalan dengan maqashid syariah dan tidak bertentangan dengan nash atau dalil-dalil qath'i. Pelaksanaan program MLM Genre ini telah sejalan dengan maqashid syariah karena kegiatan ini bertujuan untuk memberikan pembekalan materi mengenai resiko pernikahan dini, seks pra nikah dan kesehatan reproduksi, serta merencanakan pernikahan dan keluarga untuk mewujudkan keluarga yang sakinah mawaddah wa rabmah dan ketahanan keluarga dan generasi bangsa yang berkualitas.

Ketiga, bahwa kemaslahatan tersebut bersifat nyata bukan didasarkan pada praduga semata. Pelaksanaan program MLM Genre ini kemaslahatannya bersifat nyata karena kegiatan ini selain memberikan materi mengenai resiko pernikahan dini dan kesehatan reproduksi manusia juga memberikan layanan konsultasi remaja 
yang mana disebut Salam Genre, serta memberikan sosialisai mengenai materi tersebut yang disebut dengan Safari Genre dan contoh kasus disetiap materi yang diberikan guna untuk mendalami dan memecahkan permalasahan tersebut. Sehingga para remaja dapat secara langsung merasakan manfaat dari tiap materi yang telah disampaikan, serta layanan secara langsung.

Keempat, kemaslahatan harus bersifat umum atau berlaku bagi orang banyak. Dalam pelaksanaan program MLM Genre ini sudah jelas bahwa kegiatan ini demi kemaslahatan yang bersifat umum bukan pribadi. Karena dengan adanya program Multi Level Marketing dapat memberikan bekal kepada remaja yang akan menikah ataupun remaja yang sudah menikah. Dengan adanya penyampaian-penyampaian materi tersebut dapat mencegah pernikahan dini yang akan terjadi.

Kelima, berkaitan dengan dengan dampak negatif. Dampak negatif pelaksanaan program MLM Genre ini adalah jika tidak terlaksana program ini, maka masyarakat Kabupaten Pasuruan khususnya para remaja akan kurang pengetahuan dan tidak mempunyai bekal pengetahuan seputar resiko pernikahan dini, seks pra nikah dan kesehatan reproduksi wanita, serta merencanakan pernikahan dan keluarga.

Berdasarkan analisis yang sudah dipaparkan maka dapat disimpulkan bahwa syarat-syarat yang ditentukan dalam pendekatan teori maslabah mursalah sudah terpenuhi. Program MLM Genre yang diselenggarakan oleh Dinas Keluarga Berencana dan Pemberdayaan Perempuan sejalan dengan maqashid syari'ah sampai dengan syarat untuk kemaslahatan umum. MLM Genre ini diselenggarakan agar masyarakat, khususnya para remaja, memiliki bekal agar tidak terjebak dalam kasus pernikahan dini, seks pra nikah, dan agar mereka dapat merencanakan pernikahan dengan baik sehingga tidak memberikan dampak buruk bagi kehidupan atau pernikahan mereka.

\section{Penutup}

Program Multi Level Marketing Generasi Berencana (MLM Genre) merupakan jalan terbaik dalam menangani kasus pernikahan dini, yang mana dalam program Multi Level Marketing Generasi Berencaa (MLM Genre) dianjurkan untuk menikah diusia 20 tahun 
bagi perempuan dan 25 tahun bagi laki-laki. Program MLM Genre bertujuan untuk mengurangi angka pernikahan dini di kabupaten pasuruan dengan memberikan sosialisasi serta bekal dalam hal kesehatan reproduksi remaja yang meliputi tidak melakukan pernikahan di usia muda, tidak melakukan seks sebelum menikah, serta mampu merencanakan pernikahan dan keluarga demi terwujudnya keluarga yang bahagia dan sejahtera.

Pelaksanaan program MLM Genre di Kabupaten Pasuruan ini, materi yang disampaikan bisa memberikan manfaat bagi para remaja yang belum melangsungkan pernikahan ataupun yang akan melangsungkan pernikahan, sehingga telah memenuhi syarat maslahah mursalah yaitu tidak bertentangan dengan nash atau dalil-dalil qath'i, bersifat nyata, bersifat umum, dan memiliki banyak manfaat.

\section{Daftar Pustaka}

Abd Rahman Dahlan, Ushul Figh, Jakarta: Amzah, 2010.

Abdul Manan, Reformasi Hukum Islam di Indonesia, Jakarta: Rajawali Press, 2013.

Abdul Wahhab Khallaf, Ilmu Ushul Fikih Kaidah Hukum Islam, Terjemah oleh Faiz el Muttaqin, Jakarta: Pustaka Amani, 2003.

Ahmad Hamim Tohari, “Analisis Maslahah Mursalah Terhadap Beberapa Pandangan Tokoh Nadhlatul Ulama Kabupaten Sidoarjo Tentang Pernikahan Dini Akibat Hamil Pra Nikah", Artikel UIN Sunan Ampel Surabaya, 2016.

Ahmad Sanusi dan Sihari, Ushul Fiqh, Jakarta: Rajawali Perd, 2015. Aisyah dahlan, Persiapan Menuju Perkawinan Yang Lestari, Jakarta: PT. Pustaka Antara, 1996.

Asmawi, Perbandingan Ushul Fiqh, Jakarta: Amzah, 2011.

Burhanudin, Fiqib Ibadah, Bandung: CV Pustaka Setia, 2001.

Dade Ahmad Nasrullah, "Peranan KUA Dalam Menanggulangi Pernikahan Dini Di Desa PasereanKec Pamijahan Kabupaten Bogor", Artikel - UIN Syarif Hidayatullah Jakarta, 2014.

Dade Ahmad Nasrullah,Peranan KUA Dalam Menanggulangi Pernikahan Dini di Desa Pasarean Kecamatan Pamijaban Kabupaten Bogor, Artikel-UIN Syarif Hidayatullah, 2014. 
Fitria Dwi Murti dan Zayin Chudlori: Program Multi Level Marketing......

Departemen Agama RI, Al-Qur'an dan Terjemahannya, Bandung: Diponegoro, 2010.

Departemen Pendididkan Nasional, Kamus Besar Babasa Iindonesia, Gramedia: Pustaka Utama, 2008.

Djazuli, Ilmu Fiqih Penggalian, Perkembangan, dan Penerapan Hukum Islam, Jakarta: Prenadamedia Group, 2005.

Dokumen Dinas Keluarga Berencana dan Pemberdayaan Perempuan Kabupaten Pasuruan.

Fajrina Maulidina, Wawancara, Pasuruan, 25 April 2019.

H.M.A. Tihami dan Sohari Sahrani, Fikih Munakahat Kajian Fikih Nikah Lengkap, Jakarta: Rajawali Pers, 2010.

Heli Karim, Problematika Hukum Islam Kontemporer, Jakarta: Pustaka Firdaus, 2002.

Husen Muhammad, Fiqih Perempuan Refleksi Kiat atas Wacana Agama dan Gender, Yogyakarta: LKIA 2001.

K. Wantjik Saleh, Hukum Perkawinan Indonesia, Jakarta: Graha Indonesia, 1987.

Khairul Umam, Ushul Fiqih I, Bandung: CV Pustaka Setia, 1998.

Khoiruddin Nasution, Hukum Perdata Keluarga Islam Indonesia, Yogyakarta: Academia, 2009.

Kokok Adi Prayogo, Wawancara, Pasuruan, 23 April 2019.

1LM Syarifie, Membina Cinta Menuju Perkawinan, Gresik: Putra Pelajar, 1999.

Mardani, Hukum Perkawinan Islam di Dunia Islam Modern, Yogyakarta:

Graha Ilmu, 2011.

Masykur Anhari, Ilmu Ushul Fiqih, Surabaya: Diantama, 2008.

Miftahul Arifin dan A. Faishal Haq, Ushul Fiqh: Kaidah-Kaidah Penetapan Hukum Islam, Surabaya: Citra Media, 1997.

Mubasyaroh, 'Analisis Faktor Penyebab Pernikahan Dini Dan Dampaknya Bagi Pelakunya', Jurnal Yudisia, Vol.7, No. 2, 2016.

Muhamad Iqbal, Psikologi Pernikahan Menyelami Rahasia Pernikahan, Jakarta: Gema Insani, 2018.

Muizzul, Wawancara, Pasuruan, 25 April 2019

Nasrun Haroen, Ushul Figh I, Jakarta: Logas Wacana Ilmu, 1997.

Pemerintahan Kabupaten Pasuruan,'Inovasi MLM Genre Kabupaten Pasuruan Raih Penghargaan Top 25 Kovablik 
2018”, dalam https://www.pasuruankab.go.id/berita-4571inovasi-mlm-genre-kabupaten-pasuruan-raih-penghargaantop-25-kovablik-2018.html diakses pada 18 Desember 2018. Putri Nurmalitasari, Wawancara, Pasuruan, 4 Mei 2019.

Rahman, Penjelasan Lengkap Hukum-Hukum Allah (SYARIAH), Jakarta: PT Raja Grafindo, 2002.

Rani Fitrianingsih, Faktor Faktor Penyebab Pernikahan Usia Muda Perempuan Desa Sumberdanti Kecamatan Sukowono Kabupaten Jember", Artikel- -Universitas Jember, Jember 2015.

Sapiudin Shidiq, Ushul Fiqih, Jakarta: Prenadamedia Group, 2011. Satria Effendi, Ushul Fiqh, Jakarta: Kencana, 2005.

Sayyid Sabiq, Fikih Sunnah 6, terjemah, Moh Thalib, Bandung: Alma'arif, 1990.

Siti Rahayu Haditono, Psikologi Perkembangan dan Bagian-bagiannya, Yogyakarta: Gajah Mada, 1989.

SuaraPasuruan,"MLMGenreBerhasilTurunkanKasusPernikahanDi nidiKabupatenPasuruan, dalamhttps://suarapasuruan.word press.com $/ 2018 / 10 / 03 / \mathrm{mlm}$-genre-berhasil-turunkankasus-pernikahan-dini-di-kabupaten-pasuruan/ diakses pada 30 November 2018.

Suparti dan Djedjen Zainuddin, Fikih, Semarang: PT Karya Toha Putra, 1994.

Ulfiah El Lutfa, "Implementasi Peraturan Desa Penimbun No. 3 Tahun 2012 Tentang Perlindungan Anak Dalam Pencegahan Perkawinan di Usia Dini di Desa Penimbun Kecamatan Karanggayam Kabupaten Kebumen", ArtikelUIN Walisongo Semarang, 2018.

Undang Undang No.1 Tahun 1974 Tentang Perkawinan.

Undang-undang Perkawinan No. 1 Tahun 1974, Jakarta: Departemen Agama RI, 2002.

Wahabitul Magfuroh, "Penangguhan Pencatatan Perniakahan Dini Dalam Tinjauan Yuridis dan Islam (Studi Kasus Sarimpak Kidul Kotaanyar Probolinggo)", Artikel-UIN Sunan Ampel Surabaya, 2016.

Wahbah Az-Zuhaili, Fiqih Islam Wa Adillatubu Jilid 9, penerjemah, Abdul Hayyie al - Kattani, Depok: Gema Insani, 2011.

Yetti Purwaningsih, Wawancara, Pasuruan, 23 April 2019. 
Fitria Dwi Murti dan Zayin Chudlori: Program Multi Level Marketing......

Yusuf Hanafi, Kontroversi Perkawinan Anak di Bawah Umur (Chilid Marriege) Perspektif Fikih Islam, HAM Internasional, dan UU Nasional, Bandung: Cv. Mander Maju, 2011. 